\title{
PHD THESIS SUMMARY: \\ Governing by carrot and stick: a genealogy of the incentive
}

\author{
GUUS DIX
}

PhD in philosophy, May 2014

University of Amsterdam

Managers, politicians, and scientists frequently use the term 'incentive' in their explanations of human action. At the same time, individuals in the public and private sectors are now governed with the help of incentives: a bonus is an incentive for the banker to perform in an optimal way; the introduction of market forces in healthcare is an incentive for healthcare providers to use tax payers' money efficiently; the public availability of information about school performance is an incentive for school administrators and teachers to work hard. In this dissertation, I study the incentive from a theoretical and normative perspective inspired by the work of the French philosopher and historian Michel Foucault. To challenge the current self-evidence of the incentive as an explanatory term and instrument of power, I focus on the contingency that permeates the transformations in nineteenth- and twentieth-century thoughts about and uses of the carrot and the stick.

The relationship between knowledge and power is a key theme in Foucault's work. Sometimes, power is a brute phenomenon, but more often, it is cloaked in discourses that try to rationalize its exercise and justify its existence. At the end of the 1970s, Foucault (2008; 2009) began to investigate the history of these rationalizations of government in detail. In particular, he focused on two interrelated aspects of different 'governmentalities' that were developed by Western thinkers from the Middle Ages to the twentieth century. First, he studied the way the objects and objectives of political action were demarcated by different groups of (scientific) experts (see Dix 2014a). Second, he studied the development of techniques with which the behaviour of individuals and groups could be steered in a different direction. Similarly, in this thesis, I study three successive attempts to demarcate the 'incentivizable subject' as an object of knowledge and to design the techniques of power with which that subject could be governed. 
American engineers were the first professional authority in matters related to the implementation of incentives. They held a unique position in the late nineteenth century because they worked closely with the workers and foremen and, at the same time, had access to the higher echelons of management. For the engineers, the incentivization of employees was synonymous with the introduction of a variant of piece wages. Their proposals for industrial government became more refined as their understandings of wage incentives progressed. Frederick Taylor's principles of scientific management and Henry Gantt's system of charting each worker's performance are exemplary of this development.

From the 1920s onward, the authority of the engineers was challenged by social scientists from a variety of disciplines. British and American economists criticized their one-sided focus on the material motives of workers. That criticism was not lost on a group of management scientists who, in the 1930s, moved industrial research in a new direction. With backgrounds in psychology, sociology and anthropology, these management scientists developed different explanations for employee behaviour and developed a set of alternative techniques to bring the individual in harmony with him- or herself, with the working group and with managers and foremen. The proper mental and social adjustment to factory conditions came to be seen as the major incentive for people to apply themselves.

It took until the 1970s for a new rationalization of governing with the help of incentives to come into being. This time, mathematically trained economists broadened the theoretical debate on socialism versus capitalism as rival allocation mechanisms, to include a number of problems that were faced by all who governed. In their models, these economists forged a link between central economic planning and the information that was available to economic actors on the local level. The optimal allocation of goods and services, therefore, required that economic actors reported their private information to the planner honestly. But what if they were not inclined to do so? Indeed, if individuals were acting out of self-interest, it would be rational for them to withhold information from the planner. To minimize such instances of information asymmetry, the planner would have to give each individual an incentive to speak truthfully. 
The relationship between information and incentives was developed further in the economic theory of principal and agent. The principal is someone who can only achieve his or her goals if a set of agents either honestly provides the necessary information or adequately performs certain actions. According to economists, the world is inhabited by principals and agents; thereby, the idea took hold that governing with carrot and stick was not a local matter-as the engineers still thoughtbut that the information-incentive nexus could be located in a wide range of relationships between governors and governed, in both the public and the private sectors. A study of the introduction of performance pay in Dutch primary and secondary education shows that principal-agent theory played a vital role in the articulation of alleged problems in the educational system and in the proposal of suitable solutions (Dix 2014b).

In the concluding chapter I analyze a number of recurrent themes in the three incentive-infused governmentalities. First, each rationalization of government comes with a specific delimitation of the incentivizable subject and a particular role for the governor. Second, I show how a new modality of power can be extracted from my genealogy of incentivization. For despite the contingent historical shifts, the incentive is also a novel and quite coherent device that contrasts sharply with discipline as a rival technique of power (see Foucault 1995). Finally, I focus on the things that are taken for granted in the nineteenth- and twentieth-century views on and uses of the carrot and the stick as twin elements in a comprehensive program for wielding power over people.

\section{REFERENCES}

Dix, Guus. 2014a. Ricardo's discursive demarcations: a Foucauldian analysis of the formation of the economy as an object of knowledge. Erasmus Journal of Philosophy and Economics, 7 (2): 1-29. http://ejpe.org/pdf/7-2-art-1.pdf

Dix, Guus. 2014b. Expressing concerns over the incentive as a public policy device. In Concerned markets: economic ordering for multiple values, eds. Susi Geiger, Debby Harrison, Hans Kjellberg, and Alexandre Mallard. Cheltenham: Edward Elgar, 19-45.

Foucault, Michel. 1995. Discipline and punish: the birth of the prison. New York: Vintage Books.

Foucault, Michel. 2008. The birth of biopolitics: lectures at the Collège de France, 19781979. Hampshire: Palgrave Macmillan.

Foucault, Michel. 2009. Security, territory, population: lectures at the Collège de France, 1977-1978. Hampshire: Palgrave Macmillan. 
Guus Dix is lecturer in social philosophy at the Faculty of the Arts and Social Sciences of Maastricht University. He studies, from a Foucauldian perspective, the mutual reinforcement of the production of social scientific knowledge about individuals and groups and the practices and institutions in which they are governed. Extending upon his dissertation Governing by carrot and stick: a genealogy of the incentive, he now explores the advocacy of the incentive as a technique of power in education by economic experts and policy makers as well as the resistance this provokes.

Contact e-mail: <guus.dix@maastrichtuniversity.nl> 